\title{
STRATEGI PERLAWANAN PETANI TAMBANG TRADISIONAL DALAM MENJAGA KELANGSUNGAN HIDUP DI TENGAH RENDAHNYA IMBAL JASA
}

\author{
Yudhanto $^{1}$
}

\begin{abstract}
Mining activity at the old wells done by public Wonocolo and its surroundings since the 1942, and existence of oil wells traditional remains this Dutch becomes source of main living for countryside public Wonocolo and its surroundings. Mining activity done by public Wonocolo, on the way is felt is against the legislation applied namely; UU No. 44 the year 1960 jo UU No. 08 the year 1971, in the Law affirms that mining enterpasing of Migas (oil and gas) done by state with the state company (Pertamina) as the executor or mining convidential of clerk.

This research aim, to know the resistance strategy applied by the mining peasant to take care of continuity of life in the middle of the low wage's given by Pertamina. This research, applies qualitative method with approach of grounded reseacrh. Data collecting technique; nonparticipant observation and in-depth interview, and with cycle data analysis technique : data reduction, data presentation, verification and conclusion withdrawal. The result in this research, indicates that; strategy applied by the mining peasant to take care of continuity of life, by the way ; does distillation self-supportingly, mine proceeds sale without through KUD Bogo Sasono, and reduction of supply mining products.
\end{abstract}

Keyword ; Strategy, resistance of mine peasant, wage

\section{A. PENDAHULUAN}

Hengkangnya kolonial dari bumi Indonesia meninggalkan warisan tambang, khususnya; tambang Minyak dan gas yang dike-
Iola oleh rakyat secara tradisional, yakni sumur-sumur tua tinggalan kolonial Belanda.

Berdasarkan data Dirjen Migas dan Dept

1 Dosen Program Studi IImu Pemerintahan Fakultas IImu Sosial dan IImu Politik Universitas Maritim Raja Ali Haji 
ESDM, persebaran lokasi sumur-sumur tua (Sumur tua adalah sumur-sumur minyak bumi yang di bor sebelum tahun 1970 dan pernah di produksikan, serta terletak pada lapangan yang tidak diusahakan pada suatu wilayah kerja yang terikat kontrak kerja sama dan tidak diusahakan lagi oleh kontraktor. Peraturan Menteri Energi dan Sumber Daya Mineral (ESDM) No 01 Tahun 2008 tentang pedoman pengusahaan pertambangan minyak bumi pada sumur tua) yang dikelola oleh rakyat, hampir meliputi keseluruhan wilayah yang ada di Indonesia, diantaranya : di Kalimantan Timur terdapat 3.143 sumur, Sumatera bagian Selatan 3.623 sumur, Sumatera bagian Utara 2.392 sumur, Sumatera bagian Tengah 1.633 sumur, Jawa Tengah dan Jawa Timur 2.496 sumur, Seram 229 sumur, Papua 228 sumur, dan Kalimantan Selatan 100 sumur, total keseluruhan jumlah sumur-sumur tua ialah 13.824 sumur dan diantaranya 745 sumur dinyatakan masih aktif

Pada saat penelitian ini dilakukan, di Desa Wonocolo terdapat 35 sumur tua tinggalan kolonial, dari jumlah sumur-sumur tua tersebut diperkirakan mampu menghasilkan minyak mentah -crude oil- berkisar 50.000 liter atau sekitar 314 barel per hari. Aktifitas penambangan pada sumur-sumur tua telah dilakukan oleh masyarakat Wonocolo dan sekitarnya sejak tahun 1942, dan keberadaan sumur-sumur minyak tradisonal dijadikan sumber mata pencaharian utama bagi masyarakat Desa Wonocolo dan sekitarnya.

Kepala Desa Wonocolo -Lurah Wattahmemiliki 'peran staretgis' antara tahun 19421988 dalam pengelolaan dan pengusahaan sumur-sumur tua, peran tersebut diantaranya : keseluruhan keputusan berada ditangannya, terutama yang berkaitan dengan penentuan harga, cara penjualan/pemasarannya, cara pengangkutan dan pembayarannya, dan pembatasan akses warga dalam pemanfaatan Sumur-sumur tua (Lap
Penelitian, UGM;2006).

Pelaksanaan dari 'peran strategis' yang dimiliki oleh kepala desa diantaranya berdampak pada; a). ke-tidakmerataan kesejahteraan masyarakat -akses terhadap sumur-sumur tua-, b). skema pembagian keuntungan penjualan minyak yang sangat tidak adil yakni; penambang hanya mendapatkan 20\% dari total penjualan dan, c). meletakkan penambang hanya sebagai buruh tambang -bukan 'pemilik sumur'.

Kondisi ini sejalan dengan pemikiran Marshal D. Shalins (dalam Eric R. Wolf, 1985;3-4) tentang dunia ekonomi dan dan sosial mayarakat pedesaaan yakni :

Di dalam perekonomian-perekonomian primitif, bagian terbesar dari hasil produksi dimaksudkan untuk digunakan oleh penghasil-penghasilnya sendiri atau untuk menunaikan kewajiban-kewajiban kekerabatan, dan bukan untuk dipertukarkan dengan tujuan memperoleh keuntungan. Akibatnya adalah bahwa penguasaan de facto atas sarana-sarana produksi didalam masyarakat primitif terdesentralisasi, bersifat lokal dan kekeluargaan. Dengan demikian dapat diambil kesimpulan sebagai berikut : (1) hubungan-hubungan pelaksanaan dan eksploitasi dibidang ekonomi serta hubungan-hubungan sosial yang berkaitan dengan itu, yakni ketergantungan dan pertuanan, tidak diciptakan didalam sistem produksi; (2) karena tidak ada rangsangan yang ditimbulkan oleh pertukaran hasil bumi dengan sejumlah besar barang dipasar, maka ada kecenderungan untuk membatasi produksi pada barang-barang yang dapat dimanfaatkan secara langsung oleh produsenprodusennya.

Aktifitas penambangan yang dilakukan oleh masyarakat Wonocolo, dalam perjalanannya dirasakan bertentangan dengan perundang-undangan yang berlaku yakni; 
UU No. 44 tahun 1960 jo UU No. 08 tahun 1971, dalam UU tersebut menetapkan Pertamina sebagai pemegang kekuasaan atas pengelolaan dan pemanfaatan minyak dan gas bumi. Kemudian, pada tahun 1987 Desa Wonocolo masuk kedalam Wilayah Kuasa Pertambangan Pertamina Unit Ekonomi Produksi III lapangan Cepu.

Pola penanganan tambang minyak di daerah Wonocolo dan Hargomulyo, Kecamatan Kasiman, Bojonegoro, Jawa Timur, kemudian diatur dalam SK Menteri Pertambangan dan Energi No.0714.K/M.PE/88.

Dampak dari pengaturan melalui SK Mentamben No.0714.K/M.PE/88, yang sangat membebani masyarakat penambang ialah, terkait dengan rendahnya imbal jasa yang diberikan oleh Pertamina. Sebagaimana diungkapkan oleh Suyoto, imbal jasa yang diterima untuk setiap satu drum -setara 230 liter- minyak mentah diberikan imbal jasa oleh Pertamina sebesar Rp. 47. 500, menurutnya, imbal jasa yang diberikan Pertamina sangat kecil dan seharusnya setiap satu drum minyak mentah diberikan imbal jasa Rp. 100. 000, dengan rasionalisasi; dalam sehari aktivitas produksi sumur minyak, sedikitnya membutuhkan 60 liter solar untuk penggerak mesin diesel.

\section{B. Permasalahan}

Bagaimana strategi perlawanan petani tambang tradisional dalam menjaga kelangsungan hidup di tengah rendahnya imbal jasa?

\section{Metode Penelitian}

\section{C.1 Pendekatan Penelitian}

Metode yang digunakan dalam penelitian ini adalah kualitatif, dengan mengedepankan pendekatan Grounded. Penggunaan pendekatan Grounded, dikarenakan penelitian ini bertujuan memahami secara komprehensif tentang manusia petani tambang tradisional, yang oleh karenanya menuntut pekerjaan lebih dari sekedar mengamati dan mengukur indikator-indikator atau mereduksi variabel secara konsepsional, Grounded research memungkinkan peneliti untuk mengembangkan metode-metode koleksi data dan informasi yang teramat fleksibel, sehingga peneliti lebih leluasa dalam mendalami daily life manusia petani.

\section{C.2 Lokasi Penelitian}

Lokasi penelitian yakni hanya Desa Wonocolo, Kecamatan Kedewan Kabupaten Bojonegoro, Jawa Timur. Penelitian ini dilakukan pada tanggal, 18 Maret 2009 dan berakhir pada tanggal 24 juni 2009.

\section{3. Teknik Pengumpulan Data}

Ada beberapa hal yang menjadi perhatian penelitian penulis, yaitu; data primer di dapatkan melalui observasi serta berbagai keterangan dan atau masukan dari informan melalui indepth interview dan pengamatan yang kemudian dituangkan kedalam fields notes, untuk data sekunder diperoleh melalui catatan dan atau dokumen desa Wonocolo, serta pada lembaga atau instansi yang terkait dalam penelitian ini, kemudian publikasi media dan dokumen penelitian yang berkaitan dengan penelitian.

\section{3. 1. Wawancara}

Teknik yang digunakan untuk mengumpulkan data dan informasi dengan melakukan wawancara mendalam -indepth interview-.

\section{3.2. Observasi}

Observasi dalam penelitian ini menggunakan teknik non participant observation.

\section{C.4. PENENTUAN INFORMAN}

Penentuan informan dalam penelitian ini ditentukan secara acak, yang kemudian 
diperoleh informan dengan kriteria : a) memiliki pemahaman aspek budaya yang berlaku di wonocolo, b) terlibat dalam proses produksi sumur-sumur tua, c) memiliki waktu yang cukup, dan mudah memberikan informasi. Dengan komposisi sebagai berikut :

\begin{tabular}{|c|l|l|}
\hline No & Kategori Informan & Jumlah \\
\hline 1 & Penambang & 5 orang \\
\hline 2 & KUD Bogo Sasono & 1 orang \\
\hline 3 & Masyarakat Sekitar (non penambang) & 2 orang \\
\hline
\end{tabular}

\section{C.5. ANALISA DATA}

Dalam hal analisa data, pengumpulan data dan analisa data tidak menjadi suatau bagian yang terpisahkan dan berproses secara simultan, serta berbentuk siklus interaktif : reduksi data penyajian data, verifikasi dan penarikan kesimpulan.

Adapun analisa yang penulis lakukan dalam penelitian terhadap penambang tradisional desa Wonocolo adalah berinteraksi secara bolak balik sebagaimana digambarkan oleh Faisal (dalam Sabian Utsamn, 2007;57)

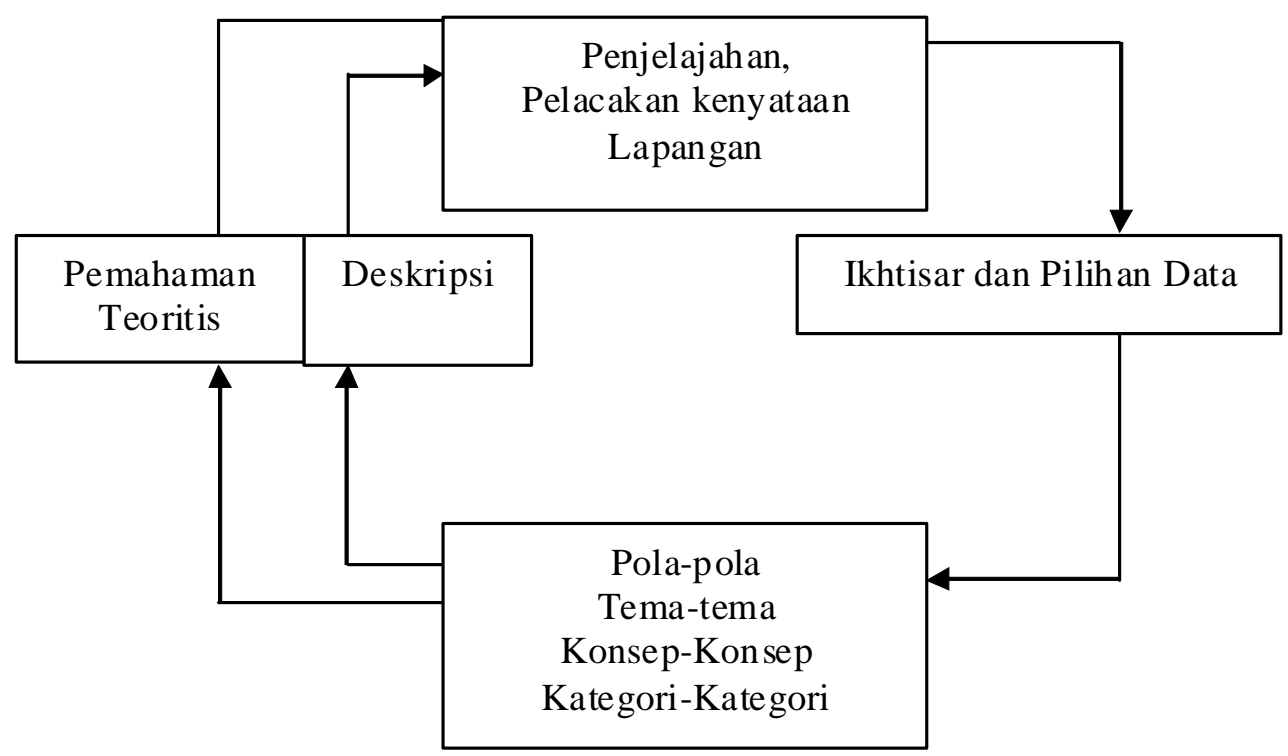




\section{Kerangka Teori}

D.1 Petani dalam Perspektif Moral Ekonomi

Kajian mengenai petani dalam perspektif ekonomi moral yang dipelopori oleh; James C. Scott, dalam bukunya "Senjatanya Orangorang yang kalah; Bentuk perlawanan seharihari kaum tani". Perlawanan yang dilakukan oleh kaum tani, dimaksudkan untuk mempertahankan kelangsungan hidup kaum tani. Dan tata perilaku ekonomi petani diikat oleh sistem moral, yang berfungsi agar terpeliharanya keamanan subsistensi.

Bentuk-bentuk perlawanan yang dilakukan oleh petani tidak sampai pada tahap pembangkangan secara terbuka dan dilakukan secara kolektif, bentuk-bentuk perlawanan ini antara lain ; mencuri kecil-kecilan, pura-pura tidak tahu, mengumpat dibelakang, membakar, dan melakukan sabotase, bentuk perlawanannya sedikit sekali atau sama sekali tidak membutuhkan koordinasi atau perencanaan, dan secara cerdas menghindari setiap konfrontasi simbolis langsung dengan pihak-pihak yang berkuasa atau dengan norma-norma elit.(Scott, 2000;40).

Ketika pemberontakan untuk membongkar struktur yang menindas terlalu mahal untuk dilakukan dan hasilnya juga tidak berketentuan - kecuali memunculkan struktur baru yang sama saja menindas atau bahkan lebih menindas lagi -, maka resistensi sehari-hari menjadi senjata yang paling ampuh bagi kaum peasant dan terutama golongan miskin(Sairin, dkk. 2002:245) Sejalan dengan pemikiran Scott, March Bloch (Scott, 2000;38) mengungkapkan ;

Karena nasibnya hampir selalu kalah dan akhirnya dibantai secara massal, maka pemberontakan yang besar sama sekali tidak taktis untuk mencapai suatu hasil yang lestari. Pertarungan yang sabar dan diam-diam yang dilakukan dengan tekad yang kuat oleh masyarakat-masyarakat desa selama bertahun-tahun akan lebih banyak mendatangkan hasil dari pada percikan-percikan gelora seketika itu. Model perlawanan yang lebih mengutamakan dahulukan selamat ini menjadi pilihan yang sangat rasional bagi petani, meliputi ; (Mustain, 2007:24-25):

a. Tidak digunakannya organisasi formal oleh petani

b. Petani mempertahankan bentuk perlawanan mereka pada skala kecil, untuk menghindari kerugian organisasi perlawananyang berlebihan terhadap mobilisasi simpatisan/massa aksi

c. Petani mengadopsi taktik "konspirasi diam" (Brown menyebutkan bahwa "konspirasi diam" petani terdiri atas tiga unsur;(1) penolakan untuk melaporkan kejahatan, (2) penolakan untuk mengidentifikasikan kriminal, (3) penolakan untuk mengungkapkan kebenaran atas suatu bentuk kejahatan. Taktik konspirasi diam dapat mengurangi kerugian yang akan diderita untuk aktifitas atomistik dibandingkan kerugian yang mereka keluarkan tanpa adanya dukungan dari masyarakat. Brown, dalam Collburn, 1989:117 dalam Mustain, 2007:24)

d. Petani melakukan aksi perlawanannya secara sembunyi-sembunyi, rahasia dan dilakukan pada malam hari - nocturnal threats by masked men -

Perlawanan yang dilakukan oleh petani tidaklah dimaksudkan untuk mengubah dominasi secara langsung, namun yang menjadi titik pijakan dari perlawanan gaya tersebut ialah bertahan hidup -survival- dalam sistem tersebut. Kemudian yang tak kalah penting dalam menjelaskan perlawanan petani ialah 'kerawanan struktural' yang melibatkan ekologi, sistem harga dan monokultur, merujuk pada pandangan Moore.

\section{D.2 Petani dalam Perspektif Teori Rasional}

Landasan utama teori rasional ialah, memandang bahwa manusia pada dasarnya 
rasional dengan selalu mengedepankan prinsip efisiensi dan efektivitas dalam setiap aktivitasnya, dengan tetap mengakui adanya faktor determinan seperti solidaritas masyarakat petani yang kuat, susbsistensi perekonomian petani dan hubungan produksi masyarakat parakapitalis, titik tolak pendekatan ini memberikan tekanan yang lebih terhadap aspek individual dalam bingkai analisisnya.

Alfred Marshall (dalam Mustain, 2007;43) menyatakan, bahwa : Manusia selalu cenderung memaksimalkan rasionalitasnya, selalu berusaha menghitung nilai sesuatu -utility--yang hendak dipertukarkan, Menurut Pareto, ada dua bentuk utility; yaitu economic utility -material- dan moral utility, keduanya menurut Waters dalam realitasnya sering dikaitkan dengan rasionalitas. Didik J. Rachbini dalam (Pratikto, 2000;14) mengasumsikan manusia pada dasarnya egois, rasional dan selalu berupaya memaksimumkan utilitas dan keuntungan untuk dirinya.

Popkin memberikan sanggahan atas pemikiran James $C$. Scoot yang memandang bahwa pelibatan diri kaum tani, dalam ekonomi pasar tidaklah disebabakan karena terancamnya keamanan subsistensi, melainkan karena kaum tani, melihat bahwa pasar lebih menjanjikan dalam hal perubahan kehidupan bagi petani, begitupun dengan keikutsertaan kaum tani dalam pemberontakan tidaklah didasarkan atas upaya resoratif untuk menjaga ke-ajegan struktur sosial lama, melainkan upaya untuk menciptakan "dunia baru" yang lebih memberikan profit, kemudian memberikan akses yang lebih besar terhadap sumber-sumber ekonomi, Popkin menguraikan :(Sairin dkk, 2002:221-222):

Beberapa representasi masyarakat preindustri mengidealkan kehidupan desa-desa petani. Gambaran-gambaran kehidupan petani yang romantis ini terlalu berlebihan dan menyesatkan kita kedalam pemikiran bahwa transformasi masyarakat ini dipaksakan pada petani dan selalu mengganggu atau merusak kesejahteraan kolektif mereka.

Selanjutnya, dalam pandangan ekonomi moral yang memandang protes-protes politik dan ke-agama-an para petani sebagai reaksi dari krisis subsistensi ataupun 'kerawanankerawanan struktural' untuk mengggambarkan dimana protes-protes itu akan terjadi, Popkin memberikan sangahannya (Pratikto, 2004;14): ...... saya berpendapat bahwa kita tidak perlu mendramatisir krisis-krisis susbsistensi sebelum petani-petani di daerah-daerah 'feodal' atau subsitensi akan mendukung gerakan revolusioner. Para petani di daerah-daerah susbsistensi mungkin kurang kecenderungannya untuk mendirikan organisasi-organisasi baru oleh mereka sendiri, tapi apabila sekutu-sekutu dari luar desa tersedia untuk menyediakan pendorong awal maka mereka akan menjadi revolusioner, bahkan menjadi lebih revolusioner dibandingkan dengan petani-petani di pusat-pusat komersial.

Studi yang dilakukan oleh Scott (1993) dan Popkin (1986) di perdesaan Asia, mengenai perlawanan petani di masa kolonial, menunjukkan tiga faktor utama yang menimbulkan kemarahan kaum petani pedesaan, yaitu perubahan struktur agraria, meningkatnya eksploitasi, dan kemorosotan status sosial.

Pada prinsipnya, perlawanan yang dilakukan oleh petani, menurut Scot dan Popkin, disebabkan oleh suatu sistem proses produksi yang menghimpit dan perlawanan yang dilakukan ialah ditujukan bagi kelangsungan hidup -economic survival- petani.

\section{E. Pembahasan}
E. 1. Dinamika Pengelolaan dan Penguasaan Tambang Minyak Tradisional di Desa Wonocolo

E. 1.1. Tambang Minyak di Era Kolonial Keberadaan ladang minyak di wilayah Jawa Tengah dan Jawa Timur, berawal dari dite- 
mukannya sumur minyak oleh seorang sarjana teknik dari Belanda yakni; Adrian Stoop. Setelah berhasil menemukan keberadaan ladang minyak di Jawa Pada tahun 1886, Adrian Stoop kemudian mendirikan perusahaan Dordtsche Petroleum Maatschappij -DPM, adalah perusahaan asing pertama di Indonesia yang mengelola minyak dan sekaligus sebagai titik awal pertambangan minyak di tanah Jawa(Lusiyati, 2008 dan Kontras, 2004).

Penemuan sumur minyak bumi, bermula dari desa Ledok sekitar $10 \mathrm{~km}$ dari Cepu, Jawa Tengah. Sumur Ledok I dibor pada bulan Juli 1893 yang merupakan sumur pertama di daerah Cepu. Pada tahun 1897, Adrian Stoop kemudian melakukan pengeboran di Gelur, dan dalam perkembanggannya usaha pengeboran sumur-sumur minyak meluas, meliputi ; lapangan minyak Kawengan, Nglobo, Semanggi, Lusi dan desa Wonocolo(Lusiyanti, 2008).

Pada tahun 1911, DPM dibeli oleh Bataafsche Petroleum Maatschappij-BPM- (BPM merupakan anak perusahaan gabungan dari Koninklijke dan Shell Transport and Trading Company (1907). "Sejarah Singkat Berdirinya Pertamina", BPM menguasai lapangan minyak Cepu, selama 31 tahun, penguasan BPM berakhir setelah Jepang menduduki nusantara (Setelah kemerdekaan Indonesia BPM kemudian berubah menjadi PTMRI, Permigan, Pusdik Migas, PPTMBG Lemigas, PPT Migas dan terakhir menjadi Pusat Pendidikan dan Latihan Minyak Bumi dan Gas (Pusdiklat Migas). "Mobil Tandai Babak Baru Cepu", Suara Merdeka, Kamis, 19 Januari 2002, dalam "Laporan Penelitian Bisnis Militer di Perusahaan Pengeboran Minyak Bojonegoro, Jawa Timur".

Pada saat terjadi perebutan kekuasaan, dengan masuknya Jepang ke Hindia Belanda -Indonesia-, Belanda tidak dengan begitu saja meninggalkan sumur-sumur minyak yang telah diusahakannya dalam keadaan normal, namun, Belanda menerapkan strategi bumi hangus atas ladang-ladang minyak di Indonesia, termasuk sumur-sumur minyak yang berada di Wonocolo.

Jepang menyadari keberadaan sumursumur minyak tersebutmemiliki nilai ekonomis, namun tentara Jepang tidak memiliki keahlian dalam mengoperasikan -proses eksploitasi dan eksplorasi- sumur-sumur minyak tersebut (Lusiyati, 2008).

Keberadaan tambang minyak pada era penjajahan -Belanda dan Jepang-, selain digunakan sebagai bahan bakar bagi armadaarmada perang dalam peperangan, minyak juga dijadikan sebagi komoditi ekspor (Pada masa Hindia Belanda terdapat dua perusahaan minyak yang beroperasi dalam penyediaan dan pemasaran BBM, yaitu BPM dan Stanvac. Sedangakan pada zaman pendudukan Jepang penyediaan dan pemasaran BBM untuk masyarakat sangat terbatas karena BBM yang dihasilkan terutama digunakan untuk keperluan perang. "Nasionalisasi Usaha Pertambangan Minyak Di Indonesia."

\section{E. 2. Di Bawah Kuasa Kepala Desa}

Hengkangnya Belanda dan Jepang, dari tanah Jawa membuat sumur-sumur tua menjadi terbengkalai, termasuk yang berada di desa Wonocolo. Keberadaan sumur-sumur tua tinggalan kolonial ini, pada mulanya belum mendapatkan perhatian dari pemerintah dan masyarakat sekitar sumur tua, dan masyarakat juga belum memiliki pengetahuan yang memadai dalam pengoperasian sumur-sumur minyak tersebut.

Di Indonesia, berdasarkan data BP Migas jumlah sumur minyak warisan penjajah kolonial Belanda sebanyak 13.824 sumur dan diantaranya 745 sumur masih aktif. Menurut data Ditjen Migas Departemen ESDM, 5.000 buah sumur-sumur tua tinggalan kolonial masih dapat diaktifkan kembali dengan produksi antara 5.000 hingga 12.000 barel per hari. Lokasi sumur tua tersebut tersebar hampir 
diseluruh Indonesia diantaranya : di Kaltim 3.143 sumur, Sumatera Bagian Selatan 3.623 sumur, Sumatera Bagian Utara 2.392 sumur, Sumatera Bagian Tengah 1.633 sumur, Jawa Tengah dan Jawa Timur 2.496 sumur, Seram 229 sumur, Papua 228 sumur, dan Kalimantan Selatan 100 sumur.

Kepala Pusat Pengembangan Tenaga Migas (PPTM), Cepu; Ir. Mokhtisar, mengungkapkan, bahwa: "Pada tahun 1890-an, Belanda membangun sekitar 550 sumur minyak, yang tersebar didaerah Blora, Tuban, dan Bojonegoro, dan sebagian besar sumur-sumur minyak tersebut terletak di Desa Wonocolo, Kabupaten Bojonegoro".

Jumlah sumur minyak tradisional peninggalan kolonial di desa Wonocolo, pada saat penelitian ini dilakukan berjumlah sebanyak 35 sumur tua yang aktif ditambang oleh masyarakat.

Sejak puluhan tahun lalu, para penambang mengais rupiah dari muncratnya minyak mentah dari sumur peninggalan Belanda tersebut. Dan aktivitas penambangan pada sumursumur tua telah ditekuni secara turun temurun oleh masyarakat. Aktivitas penambangan pada sumur-sumur minyak warisan kolonial, pada mulanya dikelola dan dimotori oleh seorang kepala desa Wonocolo, yakni; lurah Wattah Wartosentono, pengelolaan sumur-sumur tua diperkirakan telah dilakukan oleh masyarakat sejak tahun 1942.

Kepala desa Wonocolo -lurah Watahmemiliki peran yang strategis dalam usaha penambangan minyak secara tradisonal, peran tersebut meliputi : keseluruhan keputusan berada ditangannya terutama yang berkaitan dengan penentuan harga, cara penjualan/pemasarannya, cara pengangkutan dan pembayarannya.

Pada fase penguasaan sumur-sumur tua secara tradisional ini, hasil-hasil penambangan minyak dari sumur-sumur tua, dijual masyarakat secara langsung kepada tengkulak melalui koordinasi dengan kepala desa
(Sebelum ada Keputusan Presiden Nomor 7 Tahun 1987 dan Surat Keputusan Menteri Pertambangan dan Energi Nomor 177/130/ m.pe/87, tentang pelimpahan wewenang pengelolaan lapangan minyak Cepu dari PPT Migas ke Pertamina, liang sumur yang ada di sekitar Desa Wonocolo dikuasai oleh kepala desa setempat. Sumur-sumur subs di. Kondisi yang terjadi di pedesaan Wonocolo, kiranya sejalan dengan pemikiran Marshal D. Shalins (dalam Eric R. Wolf, 1985;3-4) tentang dunia ekonomi dan dan sosial masyarakat pedesaaan yakni :

Di dalam perekonomian-perekonomian primitif, bagian terbesar dari hasil produksi dimaksudkan untuk digunakan oleh penghasilpenghasilnya sendiri atau untuk menunaikan kewajiban-kewajiban kekerabatan, dan bukan untuk dipertukarkan dengan tujuan memperoleh keuntungan. Akibatnya adalah bahwa penguasaan de facto atas sarana-sarana produksi didalam masyarakat primitif terdesentralisasi, bersifat lokal dan kekeluargaan. Dengan demikian dapat diambil kesimpulan sebagai berikut : (1) hubungan-hubungan pelaksanaan dan eksploitasi dibidang ekonomi serta hubungan-hubungan sosial yang berkaitan dengan itu, yakni ketergantungan dan pertuanan, tidak diciptakan didalam sisitim produksi; (2) karena tidak ada rangsangan yang ditimbulkan oleh pertukaran hasil bumi dengan sejumlah besar barang dipasar, maka ada kecenderungan untuk membatasi produksi pada barang-barang yang dapat dimanfaatkan secara langsung oleh produsen-produsennya.

Paparan diatas sedikitnya menegaskan bahwa; penguasan sumur-sumur tua secara de facto dikuasai oleh kepala desa, dan dalam hal akses pengelolaan dan pemanfaatan sumur-sumur tua, yakni hanya yang memiliki kedekatan hubungan kekerabatan dan kedekatan emosional dengan kepala desa saja yang dapat melakukan segala aktivitas penambangan pada sumur-sumur tua menyangkut; angkat dan angkut hasil-hasil tambang. 
Dalam pelaksanannya "peran strategis" kepala desa tersebut memiliki sejumlah keuntungan, diantaranya (Laporan Penelitian, "Basis Pemberdayaan Masyarakat Desa Wonocolo Pasca Penambangan Minyak Secara Tradisional Terhadap Sumur-sumur Tua". UGM, 2006).

1. Kemudahan dalam melakukan negosiasi harga secara langsung dengan calon pembeli

2. Sistem pembayaran juga dapat dinegosiasikan, bahkan dapat diijonkan, ketika penambang terdesak membutuhkan uang untuk keperluan tertentu

3. Pemasaran lantung lebih luas, sehingga memiliki peluang menaikkan harga jual dan,

4. Koordinasi langsung dilakukan dengan perorangan, sehingga lebih luwes

Namun keuntungan-keuntungan yang dimunculkan oleh kepala desa -dalam sistem patron-klien- bukanlah berasal dari kebaikan hati pemimpin tradisional/kepala desa, hal ini dapat dilihat dari, terbatasnya akses keterlibatan masyarakat dalam melakukan eksplorasi sumur-sumur tua, kemudian bagaimana penentuan harga diputuskan, dan prosentase bagi hasil dari barang tambang tersebut. Sehingga relasi mutual patron-clients yang dibangun oleh kepala desa lebih mencerminkan nuansa eksploitatif.

Dengan skema pembagian keuntungan penjualan minyak sebagai berikut : $20 \%$ dari keuntungan penjualan minyak jadi hak 10 orang pengurus usaha. Yang 20\% lainnya dia lokasikan untuk tunjangan lima pamong desa terpilih. Sebesar $10 \%$ lagi untuk upeti anggota Muspika (Musyawarah Pimpinan Kecamatan). Dan akhirnya, menurut teori, $15 \%$ dari hasil minyak bumi untuk kas dan $25 \%$ buat pembangunan desa. Sisanya, 10\%, untuk pemeliharaan perlengkapan. Ungkap Sukoco.

Dalam pandangan Popkin bahwa desadesa kaum tani lebih tepat dilihat sebagai korporasi, bukan sebagai komun; dan hubungan patron klien harus dilihat sebagai relasi eksploitatif bukan sebagai hubungan paternal. (Sairin dkk, 2002:222). dan berikut relasi eksploitatif yang dihadirkan dari relasi patron-klien dalam penambangan sumur-sumur tua; (Laporan Penelitian, "Basis Pemberdayaan Masyarakat Desa Wonocolo Pasca Penambangan Minyak Secara Tradisional Terhadap Sumur-sumur Tua". UGM, 2006).

1. distribusi menjadi tidak merata, artinya mereka yang dekat dengan kepala desa yang lebih banyak mendapatkan keuntungan dan kemudahan

2. dampak dari butir 1 berakibat pada kesejahteraan yang tidak merata

3. para penambang hanya menjadi buruh saja

Terbatasnya akses keterlibatan bagi masyarakat sekitar, dalam melakukan eksplorasi sumur-sumur tua yang dijalankan oleh kepala desa, berakibat pada ketidak-merataan kesejahteraan masyarakat. bahkan yang terjadi kemudian ialah penumpukan kapital - material dan non material - disatu tangan yakni kepala desa (Wawancara dengan masyarakat non penambang Pak Suro).

Dalam pengamatan lapangan yang peneliti lakukan, menunjukkan; bahwa sisa-sisa bangunan rumah kediaman lurah Wattah sangat besar dan lebar, dan tergolong mewah pada zamannya memberikan bukti telah terjadinya penumpukan kapital ditangan patron-kepala desa-;

Rumah Mbah Watah memang tampak lain. Hampir semua bagian penting terbuat dari kayu jati berukir. Apa yang dipajang di dalamnya? Kendi-kendi berlapis emas. Dan di luarnya, mobil cukup banyak, apalagi buat ukuran desa. "Mbah hanya punya sembilan mobil," Ungkap Sukoco, Carik Wonocolo.

$\mathrm{Hal}$ ini kemudian diperkuat oleh pengalaman seorang warga yang pernah bertugas memperbaiki rumah kepala desa, yakni dalam hal pengupahan; warga tersebut tidak mene- 
rima upah dari tangan sang kepala desa secara langsung, namun ia disuruh mengambil upahnya sendiri disalah satu ruangan yang dipenuhi uang (Wawancara dengan masyarakat (non penambang), Pak Budi).

Penguasaan tunggal yang dibangun kepala desa selama 1942 hingga 1988 dalam hal penguasaan sumur-sumur minyak tidak hanya memadukan kekuasaan kapital materi dan non materi, namun juga membentuk kekuatan simbolik, berupa patung dirinya yang dikelilingi oleh warga, dan dimaknai sebagi bentuk pengayoman kepala desa kepada wargannya.

Pada tahun 1987, pemerintah mengeluarkan Surat Keputusan Menteri Pertambangan dan Energi Nomor 177/K/87, yang mengatur tentang pelimpahan pengelolaan lapangan minyak Cepu dari PPT Migas ke Pertamina. Wilayah Kuasa Penambangan -WKP- Pertamina Unit Ekonomi Produksi III - UEP-, seluas 973 km2, meliputi ; 4 Kabupaten, yaitu : Grobogan, Blora, Bojonegoro dan Tuban. Maka melalui penyerahan WKP ini sejumlah lapangan minyak, yaitu : Kawengan, Lapangan Ledok, Desa Wonocolo. Kecamatan Kasiman (Kedewan). Kabupaten Bojonegoro, berpindah ke Pertamina UEP III Cepu (Laporan Penelitian Bisnis Militer di Perusahaan Pengeboran Minyak Bojonegoro, Jawa Timur". Kebijakan pemerintah ini merupakan turunan dari UU No 44 tahun 1960 jo UU No. 8 tahun 1971, yang menegaskan bahwa pengusahaan pertambangan migas dilakukan oleh Negara, dengan Perusahaan Negara (Pertamina) sebagai Pelaksana atau Pemegang Kuasa Pertambangan. "Tinjauan Historis Yuridis Terhadap Pengusahaan Pertambangan Minyak Bumi Dan Gas Di Indonesia“.

Tahun 1988, menjadi akhir dari penguasaan sumur-sumur tua secara tradisional, ditandai dengan keluarnya SK Menteri Pertambangan dan Energi No.0714 K/30/M.PE/88 tentang pola penanganan tambang minyak didaerah Wonocolo dan Hargomulyo, Keca- matan Kasiman. Bojonegoro, Jawa Timur. Maka pola-pola penguasaan tradisional yang semula dikelola oleh kepala desa dengan sistem patron-clients menjadi luluh-lantah (Dalam suatu perbincangan dengan masyarakat sekitar, bahwa dengan keluarnya SK Mentamben No.0714 K/30/M.PE/88. yang berakibat pada 'punahnya' hak penguasaan secara tradisional oleh Kepala Desa yang kemudian berdampak pada kondisi fisik sang kepala desa tersebut yakni sakitsakitan dan pada akhirnya meninggal dunia, pada konteks ini menunjukkan bahwa penguasaan sumber-sumber ekonomi menjadi penting bagi keberlangsungan kekuasaan tradisional dalam bingkai menjaga realsi feodal pertuanan). Pertamina kemudian menunjuk KUD Bogo Sasono, sebagai mitra Pertamina dalam melakukan eksplorasi penambangan minyak pada sumur-sumur tua.

\section{E. 3. Masuknya Negara}

'Intervensi' ataupun perluasan Negara dalam sektor-sektor yang menguasai hajat hidup orang banyak (penguasaan SDA) dapat dibenarkan, sepanjang intervensi tersebut untuk menjaga dan merealisasikan keadilan diantara anggota masyarakat, sehingga sangat mungkin, jika kemudian terjadi peralihan dalam hal pengelolaan sumur-sumur tua. Salim G. P dalam Sabian Utsman(2007;40), mengungkapkan kaitan masuknya Negara dalam penguasaan atas sumberdaya alam dapat di benarkan dalam bingkai distribusi keadilan :

....., cukup pantas kiranya untuk mengatakan bahwa intervensi Negara yang dimaksud Ibnu Taimiyah tak lain adalah untuk menjaga dan merealisasikan keadilan diantara anggota-anggota masyarakat dan mencegah semua bentuk kerugian yang mungkin di derita oleh salah seorang anggota masyarakat dan mendengar semua bentuk kerugian yang mungkin diderita oleh salah seorang anggota msayarakat akibat tindak pelanggaran anggota lainnya didalam 
masyarakat tersebut. Dengan kata lain, intervensi Negara menghendaki agar hak-hak setiap orang terjamin secara sempurna.

Bukan hanya itu, intervensi Negara di maksudkan pula agar kepentingan umum di dahulukan dan di letakkan lebih tinggi ketimbang kepentingan pribadi. Kepentingan umum disini tidak harus berkaitan dengan kepentingan semua angota masyarakat secara keseluruhan, melainkan bisa saja hanya menyangkut orang atau kelompok tertentu tetapi yang mempunyai nuansa bagi keutuhan dan stabilitas masyarakat secara keseluruhan.

Perubahan tata kelola sumur minyak tradisional, diawali pada tahun 1987, yakni ditandai dengan penyerahan lapangan minyak yang semula dikelola oleh PPT Migas, menjadi wilayah kuasa pertambangan Pertamina UEP
III Cepu, lapangan minyak tersebut diantaranya meliputi : Kawengan, Lapangan Ledok, dan Desa Wonocolo.

Setelah adanya pelimpahan lapangan minyak tersebut, maka pengelolaan lapangan minyak/sumur-sumur tua tinggalan kolonial diatur dalam SK Menteri Pertambangan dan Energi No.0714 K/30/M.PE/88, bersamaan dengan keluarnya SK Mentamben tersebut maka tata kelola sumur-sumur tua di desa Wonocolo, tidak lagi dapat dikuasai secara tradisional oleh kepala desa.

Perubahan tata kelola sumur-sumur tua tersebut meliputi : penentuan kebijakan terkait dengan proses produksi dan pemasaran lantung,(Lantung merupakan istilah lokal/ penambang dalam menyebut minyah mentah). upah, distribusi hasil penambangan, akses terhadap sumur.

Tabel

Perubahan Tata Keloa Sumur-sumur Tua

\begin{tabular}{|c|c|c|}
\hline \multirow{2}{*}{ Isu } & \multicolumn{2}{|c|}{ Sistem Pengelolaan } \\
\hline & Kepala Desa & Sistem Upah \\
\hline $\begin{array}{l}\text { Penentuan } \\
\text { Kebijakan, terkait } \\
\text { dengan proses } \\
\text { produksi dan } \\
\text { pemasaran hasil }\end{array}$ & Kepala Desa & $\begin{array}{l}\text { Pertamina bekerja sama } \\
\text { dengan KUD Bogo Sasono }\end{array}$ \\
\hline $\begin{array}{l}\text { Distribusi hasil } \\
\text { penambangan } \\
\text { Mencakup }\end{array}$ & Tertutup & $\begin{array}{l}\text { Terbuka } \\
\text { Upah penambang, dana } \\
\text { kesusutan, biaya transport, } \\
\text { fee KUD, biaya } \\
\text { penampungan, tunjangan } \\
\text { perangkat desa dan lain-lain }\end{array}$ \\
\hline Upah & $\begin{array}{l}\text { Kemauan dan kebaikan } \\
\text { hati Kepala Desa }\end{array}$ & $\begin{array}{l}\text { Sesuai dengan kontrak yang } \\
\text { telah disepakati }\end{array}$ \\
\hline $\begin{array}{l}\text { Akses terhadap } \\
\text { sumur }\end{array}$ & $\begin{array}{l}\text { Terbatas, hanya yang } \\
\text { memiliki kedekatan } \\
\text { dengan Kepala Desa }\end{array}$ & $\begin{array}{l}\text { Terbuka, seluruh } \\
\text { masyarakat memiliki hak } \\
\text { dan kesempatan yang sama }\end{array}$ \\
\hline $\begin{array}{l}\text { Kedudukan } \\
\text { Penambang }\end{array}$ & Lemah & Kuat \\
\hline
\end{tabular}

Sumber : diadaptasi dari Laporan Penelitian, "Basis Pemberdayaan Masyarakat Desa Wonocolo Pasca Penambangan Minyak Secara Tradisional Terhadap Sumur-sumur Tua". UGM, 2006. 
Kepala desa dalam sistem pengelolaan sumur-sumur tua, memiliki peran yang sangat strategis, yakni; seluruh keputusan dalam proses produksi lantung yang meliputi; angkat dan angkut lantung dibawah koordinasi kepala desa, dan pemasaran hasil lantung pada saat ini dilakukan secara terbuka, artinya penambang dapat secara langsung memasarkan hasil tambangnya kepada pembeli.

Sedangkan pada, sistem upah, proses produksi dan pemasaran hasil tambang ditentukan oleh Pertamina dan dalam pemasaran hasil tambang masyarakat penambang, diharuskan menyetorkannya melalui KUD Bogo Ssasono. (KUD Bogo Sasono ialah badan uasaha yang bekerja untuk Pertamina dalam kegiatan mengambil dan mengangkut dan memisahkan air dan minyak yang ditambang oleh masyarakat secara tradisional. Hubungan kemitraan antara KUD Bogo sasono didasarkan atas SK Mentamben No.1285.K/ 30/M.PE/1996). Laporan Penelitian, "Basis Pemberdayaan Masyarakat Desa Wonocolo Pasca Penambangan Minyak Secara Tradisional Terhadap Sumur-sumur Tua". UGM, 2006.).
Pemasaran lantung, pasca keluarnya SK Mentamben tidak lagi dapat diperjualbelikan secara terbuka sebagaimana pada era dibawah kuasa kepala desa, masyarakat penambang diharuskan menjual hasil tambangnya ke KUD Bogo Sasono yang telah mengingkat kontrak dengan Pertamina. Kerjasama KUD Bogo Saono dengan Pertamina ini diperpanjang setiap 4 tahun sekali (Wawancara dengan Sukrihadi Ketua KUD Bogo Sasono). "Seharusnya, para penambang menyetorkan hasil tambangnya ke KUD, akan tetapi imbal jasa yang diterima para penambang dirasa gak cocok, maka penambang menjual langsung ke pengepul".

Dalam hal pemberian upah, dalam pelaksanaanya terjadi perbedaan satuan nilai yang digunakan oleh masing-masing institusi, KUD Bogo Sasono menetapkan satuan nilai imbal jasa hasil tambang/lantung didasarkan pada satuan drum, sedangakan satuan imbal jasa yang seharusnya diberikan ialah per liter, sebagaimana yang telah ditetapkan oleh pertamina. Dalam pewawancaraan yang peneliti lakukan, bahwa perbedaan satuan nilai imbal jasa ini tidak diketahui oleh masyarakat penambang.

Tabel

Perbedaan Satuan Nilai Imbal Jasa

\begin{tabular}{|c|c|c|}
\hline \multirow{3}{*}{ Tahun } & \multicolumn{2}{|c|}{ Satuan Nilai Imbal Jasa (Rp) } \\
\cline { 2 - 3 } & $\begin{array}{c}\text { Pertamina / } \\
\text { Liter }\end{array}$ & KUD Bogo Sasono / Drum \\
\hline 2001 & 231,27 & $-\cdots--$ \\
\hline 2002 & 234,96 & $---\cdot$ \\
\hline 2005 & 296,57 & $100.000 \mathrm{~s} / \mathrm{d} 150.000$ \\
\hline 2006 & 366,93 & $200.000 \mathrm{~s} / \mathrm{d} 200.000$ \\
2007 & 550,00 & \\
\hline
\end{tabular}

Sumber : Diolah dari berbagai sumber

E.4 Strategi Petani Tambang Dalam Menjaga Kelangsungan Hidup Ditengah Rendahnya Imbal Jasa

Transformasi dari ekonomi produksi untuk subsisten, menuju ke ekonomi produksi untuk komoditi, menghadapkan masyarakat petani kepada dua pilihan yakni; pertama, tetap bertahan dengan kondisi susbsistensi-nya ditengah perubahan yang terjadi dalam tata 
kelola sumur-sumur tradisional, kedua yakni "larut" dalam transformasi ekonomi tersebut, dengan mendasarkan pada persemaian keadilan ekonomi baik melalui penjualan hasil tambang melalui pintu legal - KUD Bogo Sasono - ataupun illegal - penjualan ke pengepul -.

Penyulingan lantung yang dilakukan oleh petani tambang, di karenakan rendahnya nilai imbal jasa, yang diberikan oleh Pertamina (per liter), dan adanya perbedaan nilai imbal jasa yang dipatok oleh KUD Bogosasono (per drum) bukan per liter, sebagaimana yang telah ditetapkan oleh Pertamina (Dalam kesepakatan yang dibuat oleh Pertamina dan KUD Bogo Sasono mendefinisikan kerja "penambangan" meliputi; mengangkat minyak bumi dari dasar sumur dan mengangkut minyak mentah tersebut ke bak-bak penampungan yang telah disepakati bersama yang kemudian dikirim ke Pertamina, sehingga aktivitas penyulingan merupakan aktivitas illegal - illegal refinery).

"Penyulingan yang dilakukan oleh penambang, untuk mengisi perut dan untuk membiayai kegiatan produksi, karena imbal jasa yang diberikan KUD Bogo Sasono tidak mencukupi untuk ke (Wawancara dengan penambang).

Sebelum Koperasi Bogo Sasono berdiri pada tahun 1988, kehidupan masyarakat penambang cukup sejahtera, karena mengelola sendiri minyak mentah dari sumur-sumur tradisional. Tapi setelah berdiri Koperasi Bogo Sasono yang diprakarsai oleh Pertamina, kami malah menjadi buruh saja dengan diberikan upah jasa ongkos angkut saja' (Warga minta hak pengelolaan sumur minyak tradisional.

Pada bulan oktober 2006, empat desa penghasil minyak -Kedewan, Hargomulyo, Dangilo, Mbeji dan Wonocolo- membuat kesepakatan kolektif, yang berisi tentang; penghentian pengiriman minyak mentah ke KUD Bogo Sasono. Para penambang lebih memilih melakukan penyulingan secara mandiri yang kemudian dijual ke beberapa penampungan di daerah Tuban, Blora, dan Bojonegoro, selanjutnya di kirim ke Surabaya dan Semarang.

Singkatnya, masyarakat penambang melakukan penyulingan minyak mentah sendiri merupakan usaha penambang untuk "menaklukan" pasar disatu sisi dan pada sisi lainnya, pasar tersebut digunakan oleh penambang sebagai penjaga bagi kelangsungan hidup petani tambang.

Penjulan lantung yang dilakukan oleh petani penambang tanpa melaui sistem (KUD Bogo Sasono) berdampak pada berkurangnya supply hasil tambang yang diterima Pertamina melalui KUD Bogosasono.

Penurunan suplay hasil tambang tersebut sangat siginifkan, yakni dalam keadaan normal Pertamina menerima Supply lantung dari petani penambang yang disetorkan melalui KUD Bogo Sasono sebanyak 11 hingga 12 rit tangki per hari (per tangki berisi 5.000 liter), namun, ketika petani penambang memilih melakukan penyulingan sendiri, maka supply hasil tambang yang diterima oleh Pertamina hanya mencapai 7 hingga 8 rit saja perhari

Berkaitan dengan berkurangnya suplay lantung ke Pertamina, hal ini pun dapat dimaklumi oleh pengurus KUD Bogosasono, Sukrihadi mengungkapkan :

Di karenakan nilai imbal jasa yang diterima oleh penambang sangat kecil sehingga tidak mampu menutup ongkos produksi, usaha yang dilakukan oleh KUD Bogo Sasono terkait dengan rendahnya nilai imbal jasa yang diterima oleh penambang ialah dengan cara mengajukan kenaikan nilai imbal jasa ke Pertamina. (Wawancara dengan Pengurus (ketua) KUD Bogo Sasono).

Kaitannya dengan pengurangan suplay lantung yang dilakukan oleh petani penambang, Ecstein (dalam Mustain, 2007;31) menyatakan, bahwa meskipun senyatanya pe- 
tani tampaknya pasif, sungkan dan diam, namun kaum tani dapat melakukan perlawanan atas hal-hal yang tidak mereka sukai dengan jalan mengurangi produksi atau menganggap 'sepi' atas informasi-informasi penting dari penindasnya.

Ketidakpuasan yang dialami oleh penambang akan rendahnya nilai imbal jasa, yang diberikan oleh Pertamina, tidak hanya berakhir pada penyulingan minyak mentah secara mandiri dan pengurangan supply hasil tambang, rangkaian kekesalan petani tambang tersebut berujung pada penambang tidak lagi menyetorkan hasil tambangnya ke KUD Bogo Sasono, kontestasi gerak perlawanan petani tambang selanjutnya 'di sempurnakan' dengan penjualan hasil tambang tanpa melewati pintu KUD Bogo Sasono.

Penjualan hasil tambang yang dilakukan oleh para petani tambang tidak lagi dilakukan secara tertutup dan sembunyi-sembunyi, namun hal itu dilakukan secara terbuka dan nyata, sebagaimana diungkapkan oleh Kepala Jasa Produksi PT Pertamina EP :

Kalau sekarang ini, penjualan minyak mentah tersebut keluar masih terjadi. Bahkan dilakukan secara terang-terangan, meskipun pembeli tahu jajaran Polres Blora, Jateng tidak Kompromi dengan penjualan minyak mentah keluar wilayahnya. (Pertamina Cepu Tertibkan Penjualan MInyak Mentah Tradisionil Bojonegoro. www. kapanlagi.com).

Aktivitas penjualan minyak tanpa melalui KUD Bogo Sasono, bukanlah tanpa alasan, adalah nilai imbal jasa yang diberikan oleh Pertamina sangat kecil, sebagaimana di katakan Skockpol (dalam Mustain, 20007;193) bahwa; orientasi penjulan yang dilakukan oleh petani tambang adalah untuk mencukupi kebutuhan-kebutuhan yang sifatnya spesifik dan konkrit.

Sehingga aktivitas penjualan dimaksudkan bagi keberlangsungan kehidupan petani, yakni; tercukupinya kebutuhan hidup sehari-hari dan tertutupinya ongkos produksi pengusahaan minyak dan mendapatkan lebih banyak profit. Sebagaimana diungkapkan oleh Penambang: Negdol lantung langsung nang pengepul iku batine luweh akeh, timbangane didiol nang KUD Bogo sasono, batine iso di enggo kasarane ngeh mangan sedino-dino karo di enggo tuku rencek lan solar enggo trek. Pak Yanto.(Wawancara dengan penambang).

Artinya ; menjual minyak mentah langsung ke pengepul -ilegal- itu untungnya lebih banyak, dari pada menjual minyak mentah ke KUD Bogo Sasono, keuntungannya dapat digunakan setidaknya untuk mencukupi kebutuhan sehari-hari, beli kayu bakar dan untuk beli solar untuk menghidupkan mesin truk.

Pernyataan diatas menunjukkan bahwa, petani tambang melakukan penjualan langsung tanpa melalui KUD Bogo Sasono, lebih didorong oleh adanya kewajiban untuk menjemukan kebutuhan sehari-hari -ekonomi produksi sumur minyak dan rumah tangga petani-.

\section{F. Kesimpulan}

Peralihan tata kelola dalam pemanfaatan dan pengelolaan sumur-sumur tua, yang semula berada pada kuasa kepala desa, yang kemudian dalam perkembangannya, pengelolaan dan pemanfaatan sumur-sumur tua masuk dalam wilayah kuasa penambangan Pertamina, yang mengikat kontrak kerja sama dengan KUD Bogo Sasono.

Peralihan tata kelola sumur-sumur tua, dirasakan oleh petani tambang semakin memperkecil jumlah pendapatan yang diterima oleh petani tambang, dan rendahnya imbal jasa ini, membuat petani tambang mengambil inovasi-inovasi tindakan yang bertentangan dengan ketentuan yang ada, dikarenakan adanya keharusan bagi petani tambang untuk meme- 
nuhi kebutuhan ekonomi produksi sumur minyak dan kebutuhan rumah tangga petani.

Jalan yang ditempuh petani tambang, untuk mecukupi kebutuhan produksi dan rumah tangga petani, petani menempuh jalan penyesuaian-penyesuaian, yang diwujudkan petani tambang melalui : Penjualan tanpa melalui KUD Bogo Sasono, Penyulingan secara mandiri dan Pengurangan supply tambang ke Pertamina.

Rangkaian aktivitas angkat dan angkutyang digunakan oleh petani disebabkan oleh bebarapa faktor, yakni adanya

1. Perbedaan nilai imbal jasa yang diterapkan oleh masing-masing institusi (KUD Bogo sasono dan Pertamina), perbedaan nilai imbal jasa ini berdampak pada semakin kecilnya imbal jasa yang diterima oleh petani tambang.

2. Rendahnya imbal jasa yang diberikan tidak mampu mencukupi kebutuhan produksi bagi petani tambang, dan juga kebutuhan rumah tangga petani.

3. Pilihan sikap yang digunakan oleh petani tambang, menunjukkan adanya perhitungan untung dan rugi yang melandasi perilaku petani dalam memilih pasar (legal dan ilegal) bagi pemenuhan kebutuhan produksi dan rumah tangga petani.

Penyulingan mandiri, penjulan tanpa melalui KUD Bogo Sasono dan pengurangan supply, dirasakan oleh petani tambang lebih mampu memberikan hasil yang maksimal, hal ini dikarenakan adanya surplus imbal jasa yang sangat menjanjikan yang diberikan oleh pasar ilegal.

Perubahan tata kelola pada sumur-sumur tua, senyatanya mampu memberikan penghidupan yang layak bagi petani tambang, yakni dengan memangkas biaya-biaya yang tidak dapat diketahui/diukur oleh petani, sebagaimana tertuang dalam komponen biaya penjualan hasil tambang/lantung, yakni proses gauging dan Qas, yang digunakan oleh Pertamina untuk mengurangi kadar air pada minyak mentah sesuai standar.

Singkatnya, kekayaan alam yang dimiliki oleh masyarakat Wonocolo, belum mampu memberikan penghidupan yang layak bagi penambang sumur-sumur tua, namun hal ini tentu saja tidak akan terjadi, bilamana perubahan tata kelola pada sumur-sumur tua dan hubungan kontraktual antara Penambang dan Pertamina didasarkan pada asas yang saling menguntungkan kedua belah pihak (Pertamina dan Penambang), dan bukannya saling menegasikan. 
Agger, Ben, 2003, Teori Sosial Kritis : Kritik, Penerapan dan Implikasinya, Penerbit Kreasi Wacana, Yogyakarta.

Ali, Madekhan., 2007, Orang Desa Anak Tiri Perubahan, Averros Press Kerja sama Prakarsa, Malang.

Bungin, Burhan. (ed). 2008, Metodologi Penelitian Kualitatif : Aktualisasi Metodologis ke Arah Ragam Varian Kontemporer, PT Raja Grafindo Persada, Jakarta.

Denzin, Norman K dan Yvona S. Lincoln (ed)., 1994, Handbook Of Qualitative Research, Sage Publication.

Della Porta, Donatela and Mario Diani, 1999, Social Movement : an Introduction, Blackwell Publishers.

Hudiyanto, 2004, Ekonomi Politik, Penerbit PT Bumi Aksara, Jakarta.

Loflan, John., 2003, Protes : Studi Tentang Perilaku Kelompok dan Gerakan Sosial, Insist Press, Yogyakarta

Endraswara, Suwardi., 2006, Metodologi Penelitian Kebudayaan, Gadjah Mada University Press, Yogyakarta.

Gani, Sadikin, 2006, Perlawanan Petani dan Konflik Agraria dalam Diskursus Gerakan Sosial, http;//www.prakarsa rakyat.org/ artikel/opini/artikel.

Gilbert, Alan dan Gugler, Josef., 1996, Urbanisasi dan Kemiskinan Di Dunia Ketiga, Tiara Wacana, Yogyakarta.

Kartodirdjo, Sartono., 1991, Modern Indonesia : Tradition and Transformation; a Sociohistorical Perspective, Gadjah Mada University Pers, Yogyakarta

Matulessy, Andik., 2008, Model Kausal Partisipasi Politik Aktivis Gerakan Mahasiswa, Disertasi S3 Universitas Gadjah Mada, Yogyakarta.
Mubyarto, 1982, Politik Pertanian dan Pembangunan Pedesaan, Pustaka Sinar Harapan, Jakarta.

Mustain. 2007, Petani Versus Negara: Gerakan Sosial Petani Melawan Hegemoni Negara, Ar-Ruzz Media, Yogyakarta.

Markoff, John., 2002, Gelombang Demokrasi Dunia : Gerakan Sosial dan Perubahan Politik, Terjemahan Arie Setyaningrum, Pustaka Pelajar Kerjasama Center for Critical Studies, Yogyakarta.

Nash, June., (ed), 2005, Social Movment ; an Anthropological Reader, BlackWell Publishing.

Fauzi, Noer., 2003, Bersaksi untuk Pembaruan Agraria : Dari Tuntutan Lokal Hingga Kecenderungan Global, Insist Press Kerjasama Konsorsium Pembaruan Agraria dan Lingkar untuk Pembaruan Desa dan Agraria.

_-dan Setiaji Purnasatmoko., 2002, Gerakan Sosial Mengubah Masyarakat, Wacana edisi 11, Tahun III. Insist, Yogyakarta.

Pratikto, Fadjar., 2000, Gerakan Rakyat Kelaparan : Gagalanya Politik Radikalisasi Petani, Media Pressindo, Yogyakarta.

Putra, Fadilla, dkk. 2006, Gerakan Sosial : Konsep, Strategi, Aktor, Hambatan dan Tantangan Gerakan Sosial, Averros, Malang.

Sairin, Sjafri., dkk, 2000, Pengantar Antropologi Ekonomi, Pustaka Pelajar, Yogyakarta.

Singh, Rajendra., 2001, Social Movement, Old and New: a Post-modernism Critique, Sage Publication. New Delhi.

Sutomo, Greg., 1997, Kekalahan Manusia

Petani : Dimensi manusia dalam Pembangunan Pertanian, Penerbit Kanisius, Yogyakarta.

Spardley, James P., 2007. Metode Etnografi. 
Penerbit Tiara Wacana. Yogyakarta.

Sztompka, Piotr., 2004, Sosiologi Perubahan Sosial, Penerbit Prenada, Yogyakarta

Scott, James C., 2000, Senjatanya Orangorang Kalah : Bentuk Perlawanan Seharihari Kaum Tani, Yayasan Obor Indonesia, Jakarta.

Utsman, Sabian., 2007, Anatomi Konflik dan Solidaritas Masyarakat Nelayan; Sebuah Penelitian Sosiologis, Pustaka Pelajar, Yogyakarta.

Wolf, R. Eric., 1985, Petani : Suatu Tinjauan Antropologis, Yayasan ilmu-ilmu Sosial kerjasama CV Rajawali, Jakarta.

-, 2004, Perang Petani, InsistPress, Yogyakarta.

Wiradi, Gunawan, 2000, Reforma Agraria, Insist Press, kerjasama KPA dan Pustaka Pelajar, Yogyakarta.

Vredenbreght. J, 1980, Metode dan Teknik Penelitian Masyarakat, PT. Gramedia, Jakarta.

Yustika, Ahmad Erani, 2003, Negara Versus Kaum Miskin, Pustaka Pelajar, Yogyakarta

\section{Laporan Penelitian}

Laporan Penelitian, 2004, "Bisnis Militer di Perusahaan Pengeboran Minyak Bojonegoro, Jawa Timur", www.kontras.org. Laporan Penelitian, 2006, "Basis Pemberdayaan Masyarakat Desa Wonocolo Pasca
Penambangan Minyak Secara Tradisional Terhadap Sumur-sumur Tua", Universitas Gadjah Mada, Yogyakarta.

\section{Media Online}

Duka Lara Penambang Minyak Tradisional http://bloranet.com

Kehidupan Penambang Minyak Tradisional di Perbatasan Bojonegoro-Cepu. www. jawapos.com

Mujib Rahman http://www.gatra.com/2006-0424/majalah/beli.php?pil

Diluar Rp 250 Ribu Per Drum., www.bojonegoro.go.id/indexphp

Jeritan penambang minyak tradisional. www.detik.com

Sumur minyak di Bojonegoro semburkan minyak, www.mediaindonesiaonline.com

Rebutan 'ngoreti' Sumur Minyak Tua Peninggalan Belanda. http:/l www.antarjatim.com

Sumur-sumur subsdi. http://kompas-cetak/ 0004/09/foto/sumul6.htm

Nasionalisasi usaha Pertambangan minyak di Indonesia. http://basundoro.blog.unair.ac.id/ 2009/01/3

Tinjauan historis yuridis terhadap pengusahaan pertambangan minyak bumi dan gas di indonesia

http://www.jdih.bpk.go.id/informasihukum/ hisyuridis_usahamigas.pdf 